\title{
A novel MHC- dextramer assay to identify melanoma antigen-specific CD8+ $T$ cells from solid tumor disaggregates and matched peripheral blood
}

Shen-wu Wang ${ }^{*}$, Katherine Paweletz, Michael Chastain, Robert Loberg, Gloria Juan

From 30th Annual Meeting and Associated Programs of the Society for Immunotherapy of Cancer (SITC 2015) National Harbor, MD, USA. 4-8 November 2015

\section{Background}

Cytotoxic $\mathrm{CD}^{+} \mathrm{T}$ lymphocytes (CTL) mediate target cell killing of tumor cells. New technological advances in multi-parameter flow cytometry have enabled the detection and enumeration of antigen-specific $\mathrm{CD} 8^{+}$ $\mathrm{T}$ cells (MHC-class I dextramer staining) in peripheral blood. A new dextramer based IVD test has been approved in Europe for the quantification of CMV specific CD8 T cells in peripheral blood. However, the feasibility of this type of assay in other relevant sample types such solid tumors to interrogate tumor-infiltrating lymphocytes has not yet been established.

\section{Methods}

We have developed a dextramer based assay to query the tumor-infiltrating lymphocyte population in melanoma for tumor neoepitope-specific CD8+ T cells. Through literature evaluation we identified 25 melanoma related neopeptides in major HLA subtypes, and procured the corresponding synthesized dextramer

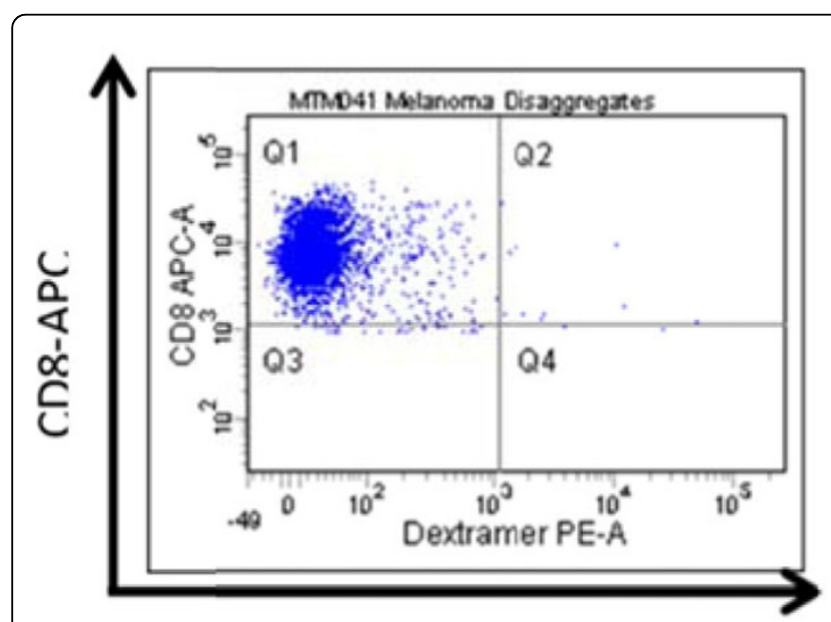

CMV-DEX-PE

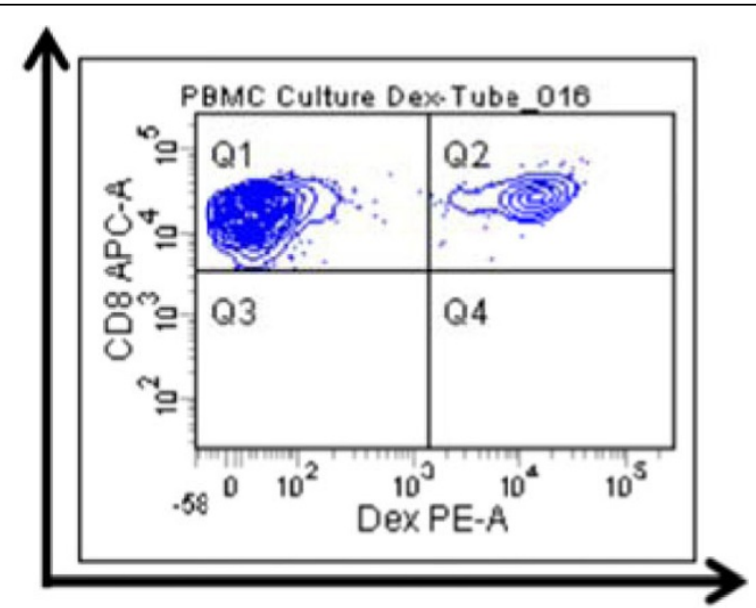

ELAGIGILTV-MART-1-DEX-PE

Figure 1 Right: MART-1 specific Dextramer detects CD8 ${ }^{+}$cell in ELAGIGILTV peptides cultured PBMC isolated from HLA A*0201 subtype. Q2 region captured CD8 ${ }^{+}$T/MART-1 specific T Cell, Left: Disaggregates of Melanoma tumor Dextramer straining.

Amgen Inc., Thousand Oaks, CA, USA 
reagents from Immudex. In addition, control dextramer reagents against human CMV and HSV1 were also generated. Assay development also included ensuring that the enzymatic tumor dissociation and cell preservation did not disrupt cell surface CD marker epitopes and TCRs from clipping during tissue processing. We also incorporated a step in the flow cytometry portion of the assay to distinguish between viable and non-viable cell populations and cellular debris, and CD3, CD8 and CD45 for specific cellular phenotyping. In parallel, high resolution 4 digit HLA typing information in HLA-A* and HLA-B* alleles was determined in peripheral blood from healthy volunteers.

\section{Results}

The Dextramer assay was performed in procured matched melanoma tumor disaggregates and peripheral blood from five subjects with matched peripheral blood and their high resolution HLA typing information. The assay platform established included a live/dead stain along with $\mathrm{CD} 3, \mathrm{CD} 8, \mathrm{CD} 45$ to isolate the cell population of interest, and then used a set of reagents includes SSDYVIPIGTY on Tyrosinase; ELAGIGILTV on MART-1; ITDQVPFSV on gp100 and YLQLVFGIEV on MAGE-A2 of melanoma related dextramers to identify antigen-specific $\mathrm{CD} 8+\mathrm{T}$ cells in both peripheral blood and tumor disaggregate.

\section{Conclusions}

We have successfully applied a fit-for-purpose flow cytometry based assay using the dextramer technology to interrogate melanoma tumor infiltrating lymphocytes. This assay can be utilized for both immune-oncology drug developments as well as for monitoring treatment responses in the clinic.

Published: 4 November 2015

Note: All human samples procured were strictly following the Amgen biologic and human sample guideline through Amgen internal sample management

doi:10.1186/2051-1426-3-S2-P109

Cite this article as: Wang et al: A novel MHC- dextramer assay to identify melanoma antigen-specific CD8+ T cells from solid tumor

disaggregates and matched peripheral blood. Journal for ImmunoTherapy of Cancer 2015 3(Suppl 2):P109.
Submit your next manuscript to BioMed Central and take full advantage of:

- Convenient online submission

- Thorough peer review

- No space constraints or color figure charges

- Immediate publication on acceptance

- Inclusion in PubMed, CAS, Scopus and Google Scholar

- Research which is freely available for redistribution

Submit your manuscript at www.biomedcentral.com/submit 